\title{
Community assembly as a promotion of participatory management in healthcare
}

\author{
Assembleia comunitária como promoção da gestão participativa em saúde \\ Asamblea comunitaria como promoción de la gestión participativa en salud
}

Daiane Mendes de Assis Réus'

ORCID: 0000-0003-3407-6794

Fabiane Ferraz"

ORCID: 0000-0003-1782-6784

Jacks Soratto"

ORCID: 0000-0002-1339-7268

Patrícia Pilatti"

ORCID: 0000-0002-2371-3017

Diego Floriano de Souza"

ORCID: 0000-0002-2597-7104

Elieser Peper Nascimento"

ORCID: 0000-0002-4303-4687

\section{ABSTRACT}

Objective: To report the participatory management experience of a Family Health Strategy by means of community assemblies. Methods: Community assemblies were performed with the population of a Family Health Strategy center in the city of Criciúma/ SC. The meetings occurred between 2016 and 2017, including health care professionals, managers, members of the organized civil society and the healthcare system clients. Results: The activity enable us to rethink the teamwork process regarding the system of health appointment scheduling and the replication of this process for all the family health teams of the municipality. Final remarks: Participatory management provided opportunities for new collective spaces that facilitate the democratization of healthcare in order to mobilize the role of the health system client in the development of more welcoming, resolute and integral health practices.

Descriptors: Unified Health System Primary Healthcare; Decentralization ; Community Participation; Health Services Administration .

\section{RESUMO}

Objetivo: Relatar a experiência de gestão participativa de uma Estratégia de Saúde da Família (ESF) por meio das assembleias comunitárias. Método: Foram realizadas assembleias comunitárias com a população adstrita de uma Estratégia Saúde da Família no município de Criciúma/SC. Os encontros aconteceram entre os anos de 2016 e 2017 envolvendo a participação de profissionais de saúde, gestores, representantes da sociedade civil organizada e usuários. Resultados: A atividade permitiu repensar o processo de trabalho da equipe no tocante a forma de agendamento de consultas e a replicação desta iniciativa em todas as equipes de Saúde da Família do município. Considerações finais: A gestão participativa oportunizou novos espaços coletivos que possibilitaram a democratização da saúde de forma a mobilizar o protagonismo do usuário na construção de práticas mais acolhedoras, resolutivas e integrais para a saúde.

Descritores: Sistema Único de Saúde; Atenção Primária à Saúde; Descentralização; Participação da Comunidade; Administração de Serviços de Saúde.

Réus DMA, Ferraz F, Soratto J, Pilatti P, Souza DF, Nascimento

EP. Assembléia comunitária como promoção da gestão participativa em saúde. [Community assembly as a promotion of a participatory management in healthcare] . Rev Bras Enferm [Internet]. 2018;71(Suppl 7):331-5. [Thematic Issue: Work and Management in Nursing]. DOI: http://dx.doi.org/ 10.1590/0034-7167-2017-0642

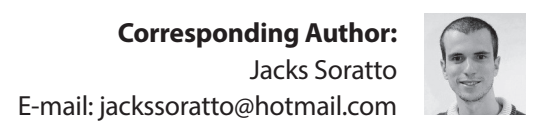

Submission: 09-25-2017
Approval: 01-27-2018

\section{RESUMEN}

Objetivo: Relatar la experiencia de gestión participativa de una Estrategia de Salud de la Familia (ESF) a través de las asambleas comunitarias. Método: Se realizaron asambleas comunitarias con la población adscrita de una Estrategia Salud de la Familia en el municipio de Criciúma / SC. Los encuentros ocurrieron entre los años 2016 y 2017 con la participación de profesionales de salud, gestores, representantes de la sociedad civil organizada y clientes. Resultados: La actividad permitió repensar el proceso de trabajo del equipo en cuanto a la forma de programación de consultas y la replicación de esta iniciativa en todos los equipos de Salud de la Familia del municipio. Consideraciones finales: La gestión participativa oportunizó nuevos espacios colectivos que posibilitaron la democratización de la salud para movilizar el protagonismo del cliente en la construcción de prácticas más acogedoras, resolutivas e integrales para la salud. Descriptores: Sistema único de Salud; Atención Primaria a la Salud; descentralización; Participación de la Comunidad; Administración de Servicios de Salud. 


\section{INTRODUCTION}

Discussion on participation and social control in public management has occurred in several social spaces in Brazil, more intensively in the healthcare area for at least three decades. The Health Reform Movement and its ideal of the right to health, which culminated with the 8th National Health Conference in 1986, was the milestone for the democratic participation of social actors in the struggle for better health conditions. The great achievement resulting from this debate was the inclusion of "health as a right of all and a duty of the State" in the Brazilian Federal Constitution of 1988 and, consequently, regulation of this right for every Brazilian citizen through Laws No. 8080/90 and 8142/90, which create the Unified Health System - (in Portuguese, Sistema Único de Saúde, SUS). SUS includes decentralization and social participation and control in health, in addition to universality, equity and integrality in its theoretical-philosophical framework ${ }^{(1)}$.

After the approval of fundamental laws for SUS construction, social participation and control have been institutionalized and exercised by different legal ways. In all those ways, actions take place at the federal, state, and local government levels. These forums of participation are spaces for militancy where thousands of Brazilians are participating in debates and somehow influencing the destiny of the health care system; however, advancement is necessary so that the forums become effective mechanisms of democratic and participative management as it was intended with the movement of the Sanitary Reform ${ }^{(2)}$.

With regards to the implementation of different structured intentions based on the implementation of SUS, the Family Health Strategy (FHS) is seen as a tool to foster and materialize community participation in the planning and organization of the health actions. Nevertheless, this service still has weaknesses, which jeopardize its political and social legitimacy, especially considering the situation of permanent dispute regarding health as a right and the different manners for its development.

The FHS prerogatives are based on multi-professional teamwork and suppose a process of democratization of institutions, as well as its openness for social participation. Teamwork also includes interaction among people involved to organize their action plans, based on a congruent communicative practice, oriented to understanding and development of a common care project, adequate to the health needs of the socials actors involved, especially the health system clients ${ }^{(3)}$.

Many challenges are still in progress for the implementation of a professional practice structured in a dialogical relationship, which builds protagonism, which allow client participation in health planning and decision-making. Such practice needs to be centered on principles of liberating education, seeking a horizontal relationship between professionals and clients, in which the ability to think critically to make decisions is not annulled(4).

Under such circumstances, some reflections are necessary: How have the family health teams (FHt) contributed to promote social participation in the health management process?

\section{OBJECTIVE}

To report a participatory management experience in a Family Health Strategy developed by means of community assemblies.
Process of development and concretization of community assemblies: experience report of co-management in health

In mid-March 2016, concern related to the limited participation of the community in the health decisions emerged at one of the internal meetings of the FHt - Morro Estevão, city of Criciúma/SC. This concept led to the idea of conducting community meetings, in order to strengthen the relationship of the $\mathrm{FHt}$ with the community, making it part of the planning process in the service activities.

This concern mobilized the FHS professionals to organize the first community assembly, which took place on April 7, 2016, at $7 \mathrm{pm}$ in the Neighborhood Community Center, purposefully alluding to the commemoration of the World Health Day. In sequence, the Community Health Agents ( $\mathrm{CHA}$ ) sent invitations prepared by the team, posters were also displayed at key areas around the community, the waiting room of the service, as well as an invitation for the population was broadcast in the local radio station by the FHS nurse. From the mobilization, the 1st Community Assembly was attended by the FHT of Morro Estevão (Criciúma/SC), the Local Health Council (LHC) and residents of the neighborhood, totaling approximately 50 people.

At the meeting, an expository methodology was used, through dialogue with the community, which included points such as: team presentation and the area covered by the FHS; the participants were clarified about the actions performed in the health unit, making this information public to the community, because some people still did not access the services or had doubts. Subsequently, an activity report was presented, by using reports exported from the Primary Care Information System (PCIS), which allowed for the community to be informed of all the procedures performed by the health team in 2015 .

However, this initial agenda was used only as a triggering device, because the team intended to have an open dialogue with the community, welcoming the suggestions and questions of the participants by means of attentive and qualified listening. Thus, after the activity report, a dialogue was held with the community, and relevant points were highlighted for the work process and the health care needs of the clients.

The main complaint reported was regarding to the number of possible appointments and the manner of scheduling patients' appointments, which until then was only via telephone call, once a week, as determined by the central management of the municipality. Participants reported problems on telephone lines that were unknown to the FHS team. In addition, some suggestions regarding reception services, scheduling arrangements and requests for new specialties were accepted for proper referrals, as well as, pacts of partnerships with local authorities were signed in order to fix some social demands that influence healthcare directly.

According to the team and participants, the meeting was beneficial, because in addition to the approximation between professionals and clients, creating a bond among them, the clients perceived themselves as parts of the process, with voices and feelings as protagonists of actions related to their health. From that date, the FHT assumed the commitment of providing the necessary changes to the problems identified in the meeting, to improve the service to the population. 
The dental office was installed, and inaugurated in October 2016, with funding sought with the aid of the local healthcare council. Tickets were provided for demand organization, more telephone lines were made available for scheduling, meetings were programmed with the residents' association, the vaccine room was reactivated with a trained professional, the number of people assisted on a daily basis became more flexible, guaranteeing spontaneous demand and welcoming.

Given the positive evaluation and regarded as very important by the participating social actors, it was agreed that the community assembly would be held annually to discuss health with the community in the area and make them protagonists of SUS development and participation process. This aspect, which theoretically seems to be obvious from the guidelines of the Brazilian health system, was not a reality in the region, because even with an active Local Health Council (LHC), this expanded participation to discuss health issues in the community was considered very important by the population.

The initiative started by the FHS of Morro Estevão became so relevant that it was shared with the managers of all the Basic Health Units (BHU) in the region in a meeting organized by the Coordination of Primary Care in January 2017. The nurse responsible for the FHS was invited to socialize the experience, as this movement effectively contributed to improvement of the teamwork process in favor of the clients. This fact reaffirmed the importance of the popular participation in the protagonism of control and inspection actions of SUS, to improve the quality of care provided to the population.

The meeting was attended by the new municipal health manager, who, based on her experience in management, promptly adopted the idea and proposed that all the Health Units of the municipality should take up this movement of community assemblies as one of the spaces for empowering the popular participation in SUS.

Thus, the City of Criciúma, by means of the Municipal Health Department (MHD), established the process of Community Assemblies in February and March 2017. For organization and disclosure purposes, a single date was established, in which all those involved had their meetings, April 26, 2017, at 7pm at health facilities or community spaces. The central agenda discussed at the assemblies was to seek solutions to local problems and discuss a new model for scheduling appointments. A total of 48 health units of the municipality held community assemblies.

According to the municipal agenda, on the day and time set by the MHD, the FHS of Morro Estevão held the second community assembly with approximately 80 people, and in addition to the community, the health team, the LHC and some neighborhood were present. The meeting agenda was announced by the healthcare team as similar to the previous year, in order to strengthen the bond and dialogue in order to seek constant improvement of the healthcare services provided to the population. The form of announcement of the assembly was the same adopted in the previous year, however the place of meeting was changed to another community center, with the purpose of giving opportunity to other people nearby.

Based on data obtained from the work process developed in the FHS in 2016 and the achievements from the previous meeting, the participants started the dialogue by questioning the main reason for complaints in the unit routine - the appointment scheduling. Until then, scheduling was done weekly, in a single time and only by telephone call, obeying the norms of the previous municipal management. With the agreement and support of the current health secretary, this method of schedule was modified by the healthcare teams, and then, presented as a suggestion to the local residents; this advanced access is structured in such a manner that there is no single day or hour to schedule appointments. The client can do it at any time of the week, either in person or by telephone call. The appointments were made by respecting and making it available to spontaneous demand according to the need and uniqueness of each person, promoting and consolidating integrality of care and welcoming as fundamental pillars in the teamwork process.

The suggestion was accepted, unanimously with the safeguard that a new meeting should be held within three months of the implementation of the new scheduling, so that the community could evaluate this decision. Doubts were resolved and suggestions on return of examinations and prescriptions of controlled medicine were well received. The meeting lasted about 3 hours; the attendees signed the book of the Local Health Council, consolidating the commitment and responsibility presented. At the meeting of the Local Health Council, which occurred in April 2018 , the scheduling process was reanalyzed, and considered by its members as an important strategy for expanding the access to the FHS clients.

\section{Reflecting about the community assemblies as spaces of social participation}

The experience reported indicates a potent strategy of social participation that enables reflection with the community about their healthcare situation. This process allowed for two important achievements: reorganization of the work process based on the logic of the service clients, in order to increase access to the FHS, and the replication of this action at the municipal level for all FHS, as requested by the municipality management.

Popular participation is a determining factor of democracy and a social conquest, and means to exercise social control in the decisions, monitoring and evaluation of the health services. The community assemblies enabled us to understand how health actions influence on people's lives, making them the protagonists of this process, making decisions at the individual and collective levels. In this sense, co-responsibility takes on a fundamental importance in the care that also encompasses the development of the service-client-management relationship ${ }^{(5-6)}$.

Popular participation should not only be developed in the bureaucratic space of legitimizing healthcare policies, such as meetings of the health councils and conferences, but it is essential that in order to achieve change, social actors lead moments that enable democratization of management, designed in the most different spaces, using dialogue and knowledge exchange, promoting understanding of health as a right ${ }^{(7)}$ towards the achievement of integrality in the health actions.

When analyzed only from the managers' perspective, the determinants of health become abstract most of the times. 
However, when considering the perspective of the community actors- healthcare system clients, they assume the necessary concreteness, because they are expressed by means of a real movement of those who experience health-disease problems. In this perspective, the clients should be understood as decision co-participants, as these actions have a direct impact on their life and in the health process. Different contexts must be considered, as well as the plurality of actors and their practices in the daily life of the healthcare spaces as elements of observation and analysis of their effects and repercussions in people's lives, thereby processes of health co-management are found ${ }^{(8)}$.

Caring is related to existential, ethical, and political dimensions, as well as in the professional-client relationship. Thus, $\mathrm{FHt}$ is considered a strategy to promote population participation; one of its functions is to promote a new relationship between the subjects, aiming a healthier life. This mechanism can be generated by a dialogical process between different types of knowledge, in which each one contributes with his/her peculiar knowledge and together they accomplish an effective interaction by valuing different experiences and expectations of life $\mathrm{f}^{(4,9)}$.

This change in health practices will only be possible by political, administrative and subjective transformations that reshape the manner that clients see and recognize themselves as citizens, i.e., persons with rights and duties ${ }^{(5,7)}$. Dialogue has been shown to be an essential tool for restructuring health care, because from these movements of speaking and listening, interaction with others as a mechanism of knowledge and understanding of the other, humanizing has become a possibility in the area of healthcare practices ${ }^{(4,10)}$.
Integrality needs to be understood as a political act associated with the right to health, therefore decisions must be made by the subjects involved in care - client, managers and professionals - which enables for public dissemination of actions and encourages public participation ${ }^{(11)}$. Thus, participation does not occur as an act of transmission of knowledge, but with the intention of dialoguing about future healthcare actions, of making decisions that aim at the best for the collectivity, therefore implying in the process of achieving better healthcare for everyone, aspects highlighted in the space of the community assembly.

\section{CONCLUSION}

Community assemblies, as spaces of protagonism and participation, are important for defining actions of the healthcare work process that consider the client needs. Therefore, they are examples of care provision that must be incorporated by the municipal health management that aim to produce increasingly welcoming practices and consider the population as right-holder, therefore with critical discernment to define what is better for them.

Community assemblies, among the spaces of popular participation, are important for strengthening the relationship between municipal management, FHS and clients, having in mind the reference points of health management. Therefore, strengthening spaces that aim at the democratization of healthcare and stimulate social participation are important initiatives that must be incorporated by $\mathrm{FHt}$ that defend integrality as the main axis of actions in healthcare, and nurses, as team managers, are responsible for mobilizing such co-management processes.

\section{REFERENCES}

1. Paim JS. A Constituição [The Citizen Constitution and the 25th anniversary of the Brazilian Unified National Health System (SUS)] Cad Saúde Pública [Internet]. 2013 [cited 2018 Sep 23];29(10):1927-36. Available from: http://dx.doi.org/10.1590/0102-311X00099513. Portuguese.

2. Escorel S. Efetivar a reforma sanitária por meio da participação social. Cad Saúde Pública [Internet]. 2013 [cited 2018 Sep 23]; 29(10):193840. Available from: http://dx.doi.org/10.1590/0102-311XCO021013.

3. Peduzzi M, Norman IJ, Germani ACCG, Silva JAM, Souza GC. Interprofessional education: training for healthcare professionals for teamwork focusing on users. Rev Esc Enferm USP [Internet]. 2013 [cited 2018 Sep 23];47(4):977-83. Available from: http://dx.doi.org/10.1590/ S0080-623420130000400029.

4. Freire P. Pedagogia do Oprimido. 59th ed. Rio de Janeiro: Paz e Terra; 2015. 107 p.

5. Cohn A, Bujdoso YL. Participação social e gestão pública no Sistema Único de Saúde [Internet]. Tempo Soc Rev Soc USP [Internet]. 2015 [cited 2017 Sep 23]; 27(1):33-47. Available from: http://www.scielo.br/pdf/ts/v27n1/0103-2070-ts-27-01-00033.pdf

6. Mitre SM, Andrade EIG, Cotta RMM. [Progress and challenges facing user acceptance in the implementation and qualification of the Unified Health System in Primary Healthcare: a review of the bibliographical output in Brazil]. Ciênc Saúde Colet. 2012 [cited 2017 Sep 23]; 17(8): 2071-85. Available from: http://dx.doi.org/10.1590/S1413-81232012000800018. Portuguese.

7. Cruz PJSC, Vieira SCR, Massa NM, Araujo TAM, Vasconcelos ACCP. [Challenges for popular participation in health issues: reflections based on popular education in the development of a local health council in communities at João Pessoa/PB]. Saúde Soc [Internet]. 2012 [cited 2017 Sep 23]; 21(4):1087-1100. Available from: http://dx.doi.org/10.1590/S0104-12902012000400025. Portuguese.

8. Campos GWS. [Democratic management and new craft: concepts to rethink integration between autonomy and responsibility in health work]. Ciênc Saúde Colet [Internet]. 2010 [cited 2017 Sep 23]; 15(5): 2337-45. Available from: http://dx.doi.org/10.1590/S141381232010000500009. Portuguese.

9. Costa GDD, Cotta RMM, Ferreira MLSM, Reis JR, Franceschini SCC. Family health: challenges in the reorientation process of the assistance model. Rev Bras Enferm. 2009 [cited 2017 Sep 23];62(1):113-18. Available from: http://dx.doi.org/10.1590/S0034-71672009000100017.

10. Medeiros LMOP, Batista SHSS. [Humanization in training and work in health: A review of the literature]. Trab Educ Saúde [Internet]. 2016 
[cited 2017 Sep 23];14(3): 925-51. Available from: https://dx.doi.org/10.1590/1981-7746-sol00022.

11. Guizardi FL, Pinheiro R. [Political participation and routine of health care management: an essay on the formative potentiality in institutional relations]. Physis (online) [Internet]. 2012 [cited 2018 Sep 23];22(2):423-40. Available from: http://dx.doi.org/10.1590/S010373312012000200002. Portuguese. 